\title{
Odrzucenie i samotność. Joachim Bauer o źródłach ludzkiej agresji
}

\author{
Anastazja MOŁODECKA*
}

\begin{abstract}
Rejection and loneliness. Joachim Bauer on the sources of human aggression: Aggression by other people, in its various manifestations, is a common phenomenon of the modern world. The mass and repetitiveness of aggressive behaviour support the position of anthropological pessimism. This position is dominant in social sciences, including psychology. The author of the paper considers whether the researchers, who show the evil of human nature, are right. While doing so she refers to Joachim Bauer's counterarguments presented in his book Schmerzgrenze - Vom Ursprung alltäglicher und globaler Gewalt [Pain threshold: on the origin of everyday and global violence] (München 2011). Bauer rejects the view that aggression is inevitable and is a natural human need. In his opinion, it is pain of rejection that is the source of human aggression.
\end{abstract}

\section{KEYWORDS}

attachment theory; pain; pain threshold; violence; social relations; attachment styles; community

* Mgr psychologii, Uniwersytet SWPS w Warszawie, psycholog w Gabinecie Psychologii Pozytywnej. E-mail: anastazjamolodecka@gmail.com. 
Agresja ze strony innych osób — w różnych jej przejawach — jest powszechnym zjawiskiem współczesnego świata. Masowość i powtarzalność zachowań agresywnych wspierają stanowisko pesymizmu antropologicznego. Stanowisko to dominuje $\mathrm{w}$ naukach społecznych, również w psychologii. Jak pisze Elliot Aronson: „człowiek jest istotą agresywną. $Z$ wyjątkiem niektórych gryzoni, żaden inny kręgowiec nie zabija z taką konsekwencją i upodobaniem osobników własnego gatunku" (Aronson, 1994: 301). Czy badacze ukazujący zło natury ludzkiej mają rację? Na powyższe pytanie próbuje odpowiedzieć Joachim Bauer w książce Granica bólu. O źródłach agresji i przemocy (Bauer, 2015b). Autor odrzuca podejście, jakoby agresja była nieunikniona i stanowiła naturalną potrzebę człowieka. Jego zdaniem powyższe stanowisko jest błędne, oparte często na subiektywnych doświadczeniach autora - na przykład teoria o wrodzonym popędzie agresji Sigmunda Freuda powstała dwa lata po zakończeniu I wojny światowej, w czasie której został ciężko ranny jego syn. Według Bauera za agresję odpowiada ból.

\section{BÓL}

Autor zauważa, że doświadczenie bólu w przeszłości może powodować dolegliwości bólowe niewiadomego pochodzenia w późniejszym czasie. Opisuje mechanizm „pamięci bólu”:

Osoby, którym w przeszłości zadano intensywne lub długo utrzymujące się bóle fizyczne, odznaczają się wyraźnie wyższym ryzykiem zachorowania na przewlekłą chorobę bólu w późniejszym życiu. Jak wykazały przeprowadzone w ostatnich latach badania, bolesne doznania przemocy odgrywają niezwykle ważną, dotychczas niedostrzeganą rolę w wywoływaniu przewlekłych chorób bólu. Rzeczywiste doświadczenia bólu w przeszłości, jak dowodzą liczne badania, spotyka się przede wszystkim u pacjentów z przewlekłymi bólami pleców, podbrzusza, ogólnym bólem mięśni (fibromialgia), jak również u pacjentów z chronicznymi bólami twarzy lub szczęki (orofacjalny zespół bólu) (Bauer, 2019: 401).

Przė̇ywany ból rodzi przemoc. Ten mechanizm psychologiczny występuje u ssaków — gdy zwierzę cierpi, rodzi się w nim agresja; gdy nie może tej agresji zwrócić ku przyczynie bólu, kieruje ją na przypadkowego przedstawiciela własnego gatunku. U ludzi, zdaniem autora, działa podobny mechanizm: (1) po przekroczeniu osobniczej granicy bólu reagujemy agresją, (2) agresję często przenosimy na niewinne osoby.

Ból stereotypowo kojarzony jest z doznaniami fizycznymi. Autor rozszerza tę tradycyjną interpretację o ból psychiczny. Jego głównym źródłem jest zdaniem Bauera społeczne odrzucenie. Deprywacja odnośnej potrzeby boli na równi z cierpieniem cielesnym: 
A zatem wiemy już, że przekroczenie granicy bólu ludzkiego ciała stanowi bodziec wyzwalający reakcję agresywną. Jednak bez wątpienia paradygmat wiążący agresję z bólem fizycznym jest dalece niewystarczający dla wyjaśnienia całego spektrum ludzkiej przemocy. Drogę do kompleksowego ujęcia zjawiska agresji człowieka otworzyło dopiero pewne odkrycie o znaczeniu prawdziwie przełomowym: „z punktu widzenia mózgu” granica bólu może zostać przekroczona nie tylko wtedy, gdy jednostka doznaje cierpienia fizycznego - ośrodki bólowe w mózgu uaktywniają się również, kiedy człowiek doświadcza dyskryminacji, upokorzeń, odrzucenia (Bauer, 2015b: 87).

Odrzucenie jest tu rozumiane szeroko - nie chodzi jedynie o wyraziste postacie wykluczenia, jak lekceważenie czy dyskryminacja innych osób, ale również o te bardziej subtelne, jak opuszczenie przez najbliższe otoczenie, bycie zapomnianym, samotność. Bauer pisze:

z wykluczeniem społecznym mamy do czynienia nie tylko wtedy, gdy człowiek jest traktowany przez innych z pogardą, lekceważony albo bezpośrednio dyskryminowany. Również osoby osamotnione, nieprzynależące do żadnej grupy społecznej — są ludźmi wykluczonymi (Bauer, 2015b: 109).

Brak związków, alienacja, wykorzenienie - stany te nasilają tendencję do przemocy. Osoby opuszczone wykazują większą skłonność do zachowań agresywnych niż te, które żyją w związkach.

Autor opisuje neuronalny mechanizm narodzin agresji. Ukazuje, w jaki sposób cierpienie związane z poczuciem odrzucenia bądź niesprawiedliwości wpływa na procesy somatyczne (spadek poziomu neuromediatorów odpowiedzialnych za samopoczucie jednostki) i w efekcie na choroby ciała i duszy, których objawem mogą być wybuchy agresji:

Bez znajomości nastawionego na kooperację i uczciwość układu motywacji ludzkiego mózgu nie sposób zrozumieć reguł, jakimi rządzi się agresja. „Z perspektywy mózgu” odmowa akceptacji społecznej i niesprawiedliwe traktowanie oznaczają nie tylko zablokowanie układu motywacyjnego (już samo to może mieć poważne skutki) - efektem permanentnego braku akceptacji może być krytyczny spadek poziomu neuromediatorów ważnych dla utrzymania dobrostanu jednostki, a co za tym idzie - choroby psychiczne i somatyczne. Ktoś, kto traktuje drugiego człowieka niesprawiedliwie, dotyka jego neurobiologicznej granicy bólu i musi się liczyć z agresją (Bauer, 2015b: 61).

\section{ROLA RELACJI SPOÆECZNYCH}

Pierwszym myślicielem, który dostrzegł społeczny wymiar natury ludzkiej, był Arystoteles: „Kto zaś nie potrafi żyć we wspólnocie albo jej wcale nie potrzebuje, będąc samowystarczalnym, bynajmniej nie jest członem państwa, a zatem jest albo zwierzęciem, albo bogiem. Wszystkim ludziom właściwy jest z natury pęd 
do życia we wspólnocie” (Arystoteles, 2001: 1253a, 28). Z kolei jako prekursora badań naukowych w kierunku potrzeby więzi autor wymienia Charlesa Darwina, który pisał o potrzebie wspólnoty i o bólu, jaki wywołuje strata ukochanej osoby. Również w piramidzie potrzeb Abrahama Maslowa (Maslow, 2018) potrzeby społeczne (pragnienie przynależności do wspólnoty i akceptacji z jej strony, a na wyższym poziomie - szacunku i uznania ze strony otoczenia) opisane są jako fundamentalne. Kontynuując tę tradycję, Bauer twierdzi, że głównym ludzkim instynktem jest nie agresja, lecz potrzeba przynależności. Człowiek jako istota społeczna odczuwa przemożne pragnienie kontaktów społecznych. Nic jego zdaniem nie motywuje człowieka tak silnie, jak potrzeba wspólnoty.

Człowiek znajduje, zgodnie z wyrokiem wszystkich mędrców, najwyższe zadowolenie w tym, kiedy postępuje za określonymi impulsami, mianowicie za instynktami społecznymi. Gdy działa dla najwyższego dobra innych, doświadczy uznania bliźnich i zdobędzie miłość tych, z którymi razem żyje; a ten zysk jest bez wątpienia radością najwyższą, jakiej może dostąpić na naszej Ziemi (Bauer, 2015: 27).

\section{ŚWIAT BEZ AGRESJI}

Rozwój cywilizacji zachodniej oznaczał z jednej strony emancypację jednostki i wzrost jej wolności osobistej, z drugiej jednak strony - wykorzenienie z tradycyjnych wspólnot i społeczną alienację. Pomiędzy wymogami cywilizacji a naturalnymi potrzebami człowieka pojawiło się napięcie, odbierane przez jednostki jako dylemat: natura (wspólnotowość prowadząca do zniewolenia) - kultura (indywidualizm prowadzący do samotności). Ludzkość szukała różnych rozwiązań, które pomogłyby człowiekowi dostosować się do wymogów współczesności, a jednocześnie uporać się z narastającym poczuciem odrzucenia. Jednym z patentów, zdaniem Bauera, okazała się religia, której celem było odzyskanie poczucia wspólnoty, utraconego w procesie rozwoju cywilizacji. Innym - moralność:

rozwinięcie systemów moralnych było reakcją na alienację człowieka spowodowaną procesem cywilizacyjnym. Funkcją systemów moralnych jest bowiem czuwanie nad tym, by człowiek w obliczu cywilizacyjnego wyobcowania nie zapomniał o swoim właściwym powołaniu (Bauer, 2015b: 246).

Najlepszym jednak sposobem na zmniejszenie bólu, jaki w związku z samotnością, poczuciem niesprawiedliwości i odrzucenia odczuwa dziś wiele jednostek, jest według autora poprawa relacji społecznych. Taka ich korekta, która wzmacnia rolę współpracy, buduje wspólnotę, rodzi wzajemne zaufanie:

można oczekiwać obniżenia poziomu agresji tam, gdzie dobre relacje społeczne i wzajemne zaufanie stanowią wysoką wartość. $Z$ nasileniem przemocy należy się liczyć 
w społeczeństwach, w których dominuje poczucie zagrożenia, a układy społeczne sprzyjają upokarzającej marginalizacji części ludności (Bauer, 2015b: 71).

Bauer apeluje również o stonowanie nierówności materialnych:

ekonomiczne nożyce zamożności nie powinny się zanadto rozwierać. Mózg ludzki ma neurobiologicznie zakorzeniony zmysł sprawiedliwości - sprzeniewierzenie się zasadom elementarnej uczciwości dotyka granicy bólu i pociąga za sobą agresję (Bauer, 2015b: 302-303).

\section{KONCEPCJA BAUERA A TEORIA PRZYWIAZZANIA}

Koncepcja Bauera wskazująca na rolę dobrych relacji międzyludzkich w prawidłowym rozwoju człowieka i na negatywne konsekwencje deprywacji potrzeb społecznych może być uznana za kontynuację i uzupełnienie teorii przywiązania (attachment theory). Chociaż sam autor nie poświęca tej teorii specjalnej uwagi (wspomina ją zaledwie raz), jego wizja natury ludzkiej i diagnoza zaburzeń zachowania są zgodne z ustaleniami poczynionymi przez psychologów na jej właśnie gruncie.

Teoria przywiązania, której twórcą był John Bowlby, kładzie nacisk na relacje wczesnodziecięce. W dzieciństwie na podstawie relacji dziecka z osobami znaczącymi (najczęściej z matką) kształtują się określone style więzi. Uczennica Bolby'ego, Mary Aisworth wraz ze współpracownikami przeprowadziła serię eksperymentów (Aisworth et al., 1978), w wyniku których uczeni wyróżnili bezpieczny styl więzi i dwa pozabezpieczne: unikający i lękowo-ambiwalentny. Bezpieczny styl przywiązania (występuje u 70\% dzieci) budowany jest poprzez częste kontakty z opiekunem i wrażliwość opiekuna na sygnały ze strony dziecka. Unikający styl przywiązania (20\% dzieci) kształtuje się jako efekt braku bliskiego kontaktu i wsparcia w sytuacjach trudnych emocjonalne, stwarzających zagrożenie. Unikanie bliskości jest strategią chroniącą dziecko przed przyszłym zranieniem. Styl lękowo-ambiwalentny (10\% dzieci) charakteryzuje się niepokojem o trwałość związku z najbliższą osobą. Dziecko odczuwa silny lęk przed rozstaniem. Niemowlęta tak klasyfikowane oscylują pomiędzy poszukiwaniem bliskości i kontaktu z mamą a opieraniem się przed kontaktem i interakcją.

Style więzi ukształtowane w dzieciństwie mają wpływ na późniejsze funkcjonowanie psychiczne oraz społeczne osób dorosłych.

Podstawą teorii stylów przywiązania jest następujące założenie: sposób, w jaki nauczymy się przywiązywać do innych osób we wczesnym dzieciństwie, wyznacza nasz przyszły jako osób dorosłych - sposób nawiązywania kontaktów. Osoba, która przyswoiła sobie styl oparty na poczuciu bezpieczeństwa, potrafi tworzyć dojrzałe, trwałe związki. Ludzie, dla których charakterystyczny jest styl przywiązywania się oparty na unikaniu, mniej ufają innym i trudno nawiązują bliskie kontakty. Osoby zaś z lękowo-ambiwalentnym 
stylem przywiązywania się chciałyby być bliżej swoich partnerów, jednak mają obawy, że ci nie odpowiedzą im tym samym (Aronson, Wilson, \& Akert, 1997: 443).

Styl bezpieczny charakteryzuje się pozytywnym obrazem siebie oraz innych. Osoby takie mają stabilne poczucie własnej wartości. Zazwyczaj tworzą długotrwałe, stabilne i satysfakcjonujące związki, które cechują się wzajemnym szacunkiem, zaufaniem, przyjaźnią i zaangażowaniem. Związki takich osób są bezinteresowne i pozbawione wzajemnych gier. Styl lękowy charakteryzuje się negatywnym modelem siebie i innych. Osoby reprezentujące taki styl posiadają niestabilne poczucie własnej wartości, zabiegają o aprobatę otoczenia, w związkach obawiają się odrzucenia przez bliskie osoby. Wykazują wysoki poziom lęku, są nadmiernie czujne oraz silnie się angażują. Boją się odrzucenia, utraty miłości. Poszukują dowodów miłości i uznania. Łatwo wpadają w złość i nie potrafią kontrolować tej emocji. Ich związki cechują się dużym wahaniem uczuć, ochotą zlania się z partnerem. Często są zaborcze, zazdrosne. Styl unikający z kolei charakteryzuje się dążnością do niezależności, negacją potrzeby związków i bliskości. Osoby o tym stylu więzi raczej nie wchodzą w długotrwały związek romantyczny. Nie czują się komfortowo w bliskim kontakcie, wolą nie być zależne od innych ludzi. Uważają siebie za osobowości silne, na poziomie nieświadomym boją się odrzucenia, zbytniej zależności, bezradności. Innych postrzegają jako karzących, odrzucających albo kontrolujących.

Pozabezpieczne style więzi są źródłem problemów emocjonalnych i zaburzeń zachowania osób dorosłych. Powodują różne problemy życiowe: kłopoty z zaangażowaniem emocjonalnym lub, wręcz przeciwnie, z nadmiernym uzależnieniem się od drugich. Nieumiejętność zbudowania satysfakcjonującego związku staje się dla tych osób, mimo stosowania mechanizmów ochronnych, źródłem frustracji i może generować skłonność do zachowań agresywnych.

Bauer w książce Granice bólu... odrzuca teorie mówiące o siłach destrukcyjnych tkwiących w psychice człowieka (psychoanaliza) czy o jego biologicznej skłonności do agresji (psychologia ewolucyjna). Dowodzi, że człowiek z natury jest nastawiony na współpracę i zgodne życie z innymi. Dopiero przekroczenie tytułowej „granicy bólu” wywołuje w nim agresję, często kierowaną na przypadkowe osoby. Zdaniem autora świadomość przyczyn zachowań przemocowych daje nam narzędzia przeciwdziałania złu. Diagnoza stwarza możliwość prewencji. Taki diagnostyczno-prewencyjny był cel autora:

Celem mojej książki jest uzmysłowienie, że sposób, w jaki podchodzimy do problemu ludzkiej agresji, ma dla naszego życia decydujące znaczenie, ponieważ w zależności od tego, jak rozumiemy zjawisko agresji, tak będziemy na nie reagować (Bauer, 2015b: 40). 
Koncepcja genezy agresji Bauera przypomina teorię agresji frustracyjnej Johna Dollarda i Neala E. Millera (w jej pierwotnym wariancie z 1939 roku), według której agresja jest automatyczną reakcją na frustrację, czyli negatywne emocje powstałe w wyniku deprywacji potrzeb, kierowaną na źródło frustracji albo (z różnych przyczyn) przekierowaną na inne osoby. Wspomniani autorzy wśród czynników wywołujących frustrację, a następnie akty agresji, wymieniali, podobnie jak obecnie Bauer, niski status społeczny (ubóstwo, bezrobocie). Zgodnie z tą teorią związek frustracji z agresją jest bardzo ścisły: frustracja zawsze rodzi agresję oraz nie ma agresji bez wcześniejszej frustracji. Warto zauważyć, również w kontekście teorii Bauera, że współcześni psychologowie społeczni kwestionują ów ścisły związek obu zjawisk.

Przy tej okazji warto wspomnieć ogólny model agresji (General Aggression Model, GAM) Craiga A. Andersona i Brada J. Bushmana (Anderson \& Bushman, 2002), zgodnie z którym agresja jest efektem działania wielu różnorodnych czynników. Należą do nich: przeżycia jednostki (na przykład ból, złość), wyuczone struktury poznawcze (wrogie myśli), pobudzenie fizjologiczne (szybki puls, wzrost poziomu kortyzolu czy adrenaliny), czynniki osobowościowe (na przykład temperament), cechy sytuacji (prowokacja, alkohol, wysoka temperatura i inne) oraz, co należy podkreślić, indywidualny wybór między zachowaniem impulsywnym a przemyślanym. Zatem ból, który jest w centrum zainteresowania Bauera, w perspektywie teorii GAM okazuje się jedynie jednym z wielu motywatorów agresji. Model Andersona i Bushmana lepiej wyjaśnia znane z doświadczenia fakty, że nie każdy cierpiący (na przykład torturowany, ciężko chory czy doświadczający niesprawiedliwości) staje się agresywny. W perspektywie tego modelu możemy też mówić o moralnej odpowiedzialności za akty agresji, podczas gdy w opartej na determinizmie społecznym koncepcji Bauera ginie kategoria indywidualnego sprawstwa i podmiotowej odpowiedzialności za przemoc. Odpowiedzialność za czyny jednostek w koncepcji Bauera spada na system. Skoro według niemieckiego uczonego agresor w rzeczywistości sam jest ofiarą, to rodzą się pytania: Czy ta teoria usprawiedliwia agresję, tłumacząc ją bólem, nad którym nie mamy kontroli? Jeśli agresja jest wywołana przez źle zorganizowane społeczeństwo, to czy możemy karać sprawców przemocy?

Bauer ukazuje emocjonalną i społeczną cenę wykluczenia. Nie odpowiada jednak na pytanie, dlaczego ludzie wykluczają innych. Dlaczego porównują się i pragną wywyższyć w każdej istotnej dziedzinie? Bez tej odpowiedzi nie opanujemy potrzeb rywalizacyjnych, które pchają jednostki do walki o pierwszeństwo i w konsekwencji powodują frustrację u „przegranych” w tej walce. Ograniczenie motywacji rywalizacyjnej i powstałych w jej efekcie nierówności społecznych wydaje się niemożliwe. Byłoby też sprzeczne z interesami ludzkości, której rozwój cywilizacyjny bazuje na mechanizmie konkurencji. Jak zatem eliminować u słabszych jednostek i grup społecznych poczucie odrzucenia, gorszości, niesprawiedliwości, nie hamując jednocześnie postępu? Co jest ważniejsze: 
pokój społeczny w świecie bez agresji czy dobrobyt w świecie nastawionym na rywalizację?

Jak widać, książka Bauera prowokuje szereg pytań, ukazuje dylematy etyczne, inspiruje do dalszych przemyśleń i badań. Jego propozycja, aby zwrócić się ku więziom rodzinnym, budować ramy społecznej współpracy, walczyć z dyskryminacją, uczyć od najmłodszych lat wzajemnej pomocy i wartości egalitarnych, jest bardzo ważnym głosem $\mathrm{w}$ dyskusji na temat źródeł ludzkiej agresji i metod przeciwdziałania przemocy we współczesnym świecie.

\section{BIBLIOGRAFIA}

Ainsworth, M.D., Blehar, M.C., Waters, E., \& Wall, S.N. (1978). Patterns of attachment: A psychological study of the strange situation. Hillsdale: Lawrence Erlbaum.

Anderson, C.A., \& Bushman, B.J. (2002). Human aggression. Annual Review of Psychology, 53(1), 27-51.

Aronson, E. (1994). Człowiek — istota społeczna. (Przeł. J. Radzicki). Warszawa: Wydawnictwo Naukowe PWN.

Aronson, E., Wilson, T.D., \& Akert, R.M. (1997). Psychologia społeczna. Serce i umyst. (Przeł. A. Bezwińska et al.). Poznań: Wydawnictwo Zysk i S-ka.

Arystoteles (2001). Polityka (t. 6, s. 25-226). W: Arystoteles. Dzieła wszystkie. (Przeł. L. Piotrowicz). Warszawa: Wydawnictwo Naukowe PWN.

Bauer, J. (2008). Empatia. Co potrafia lustrzane neurony?. (Przeł. M. Guzowska-Dąbrowska). Warszawa: Wydawnictwo Naukowe PWN.

Bauer, J. (2015a). Co z ta szkoła? Siedem perspektyw dla uczniów, nauczycieli i rodziców. (Przeł. A. Lipiński). Słupsk: Dobra Literatura.

Bauer, J. (2015b). Granica bólu. O źródłach agresji i przemocy. (Przeł. M. Skalska). Stupsk: Dobra Literatura.

Bauer, J. (2019). Pamięć komórkowa naszego ciała. (Przeł. A. Trybulska). Białystok: Wydawnictwo Vital.

Bowlby, J. (2016). Przywiązanie. (Przeł. M. Polaszewska-Nicke). Warszawa: Wydawnictwo Naukowe PWN.

Doliński, D. \& Grzyb, T. (2017). Postuszni do bólu. Sopot: Wydawnictwo Smak Słowa.

Dollard, J. et al. (1998). Frustration and aggression. London-New York: Routledge.

Freud, Z. (1982). Wstęp do psychoanalizy. (Przeł. W. Zaniewicki \& S. Kempnerówna). Warszawa: Państwowe Wydawnictwo Naukowe.

Lorenz, K. (1972). Tak zwane zło. (Przeł. A.D. Tauszyńska). Warszawa: Państwowy Instytut Wydawniczy.

Maslow, A. (2018). Motywacja i osobowość (cz. 1). (Przeł. J. Radzicki). Warszawa: Wydawnictwo Naukowe PWN.

Milgram, S. (1963). Behavioral study of obidience. Journal of Abnormal and Social Psychology, 67, 371-378.

Milgram, S. (1965). Some conditions of obedience and disobedience to authority. Human Relations, 18, 57-75.

Wojciszke, B. (2011). Psychologia społeczna. Warszawa: Wydawnictwo Naukowe Scholar.

Zimbardo, P. (2008). Efekt Lucyfera. Dlaczego dobrzy ludzie czyniq zło?. (Przeł. A. Cybulko et al.). Warszawa: Wydawnictwo Naukowe PWN. 